\title{
PRODUCTION AND ECONOMIC SPECIFICITIES IN GROWING OF DIFFERENT GARLIC VARIETIES
}

\author{
Ibrahim Totič ${ }^{1}$, Stevan Čanak ${ }^{2}$
}

\begin{abstract}
Summary
Importance of garlic is enormous for both human health and cookery. Garlic is a crop whose production does not endanger the agro-system and the eco-system, which is of special significance for organic food production. Considering that growing garlic is based on the application of agro-ecological and agro-economic principles, this paper describes the soil preparation process for planting, planting technology, application of agro-technological measures. It also gives an account of the basic characteristics of the planting material, its extraction and storage. The subject of research of this paper is to determine yield of different garlic types on two different locations in Serbia. It also aims to determine costs and calculations based on variable costs, as well as to compare economic results of production of different garlic types on family-own small-scale farms.
\end{abstract}

Key words: garlic, production technology, contribution margin.

JEL: $L 23, Q 19$

\section{Introduction}

It is unthinkable that a modern man, occupied with his creative enthusiasm, exposed to his dynamic and daily stressful activities, can allow himself not to consume five basic products: garlic, honey, corn, apples and brandy. Each of these products possesses multiple qualities, but garlic (Allium sativum) is without any doubt dominant in this respect. It is interesting that high quality leeks (Allium ampeloprasum var. porrum) did not receive any favourable attention from farmers, and that it is still rarely being cultivated. Garlic is to vegetable growing what the walnut is to fruit-growing (Engeland, 1991), ever since the first areas of growing garlic. This is the first reason why growing garlic is the topic of this paper. The second reason is that the author himself grows it, and has special respect considering it a cult crop.

1 Ibrahim Totić, Ph.D., Assistant professor, Department for Economic sciences, State University of Novi Pazar, Vuka Karadžića nn, 36300 Novi Pazar, Serbia, Phone: +381 203177 52, E-mail: itotic@np.ac.rs

2 Stevan Čanak, Ph.D., Assistant, Department for Chemical - Technological sciences, State University of Novi Pazar, Vuka Karadžića nn, 36300 Novi Pazar, Serbia, Phone: +381 203177 52, E-mail: scanak@np.ac.rs

EP 2014 (61) 4 (915-928) 
Agarlic bulb consists of 8 to 12 cloves, which in their concentrated form contains more than two hundred biologically active substances (Anwar et al., 2009). Scientific research has indicated that they consist of ethereal oils, vitamins (A, B1, B2 and C), minerals (sulphur, potassium, iron, iodine, phosphorus, and selenium), amino-acids, enzymes and other components such as inuline, adenosine and alicine (Schwartz and Krishna, 1999). Garlic is used as a dietary supplement and as a medicine. Its high quality, beneficial effect and overall positive effect on human health have been known since ancient civilizations (Jones and Goebel, 2001). However, its more widespread use began after its energy, nutritional and medicinal values were scientifically proven. Increased demand for garlic led to an increase in the amount of planted garlic almost all over the world (in parts of the Mediterranean, Europe, Asia, and North America). Today modern and expansive production is primarily related to China and the United States of America, Korea, but also to other regions of the world where all the various types of garlic are somewhat unfamiliar. Thus, interest in growing garlic has been increasing, both among the buyers for the purpose of consumption and among producers as well, due to its high yield (Renoux, 2005).

Research has shown that garlic, either fresh or processed, still possesses many extraordinary health benefits. Its pungent smell (Block, 2010), which is usually referred to in a negative context, can be reduced in several ways. It is produced by allyl methyl sulphide - $A M S$, an unstable liquid (Verma et al., 2012), derived from sulphurous compounds which, as a part of metabolic processes are absorbed from the blood, travel to lungs and from there to mouth where they cause white odour (Alnaqeeb et al. 1996). Parsley, yoghurt and/or some types of alcoholic beverages are used to eliminate this odour. Even with such odour, it is an effective form of protection against various kinds of illnesses, insects, etc. (Pritts, 2009).

\section{Aim of the paper}

The very attempt to grow garlic along an area of four rows (approximately $16 \mathrm{~m}^{2}$ ) on a surface of $640 \mathrm{~m}^{2}$, seems somewhat of an adventure - before all, due to the location which spans on two municipalities; secondly, because of the different (albeit slightly) geomorphological features of the land; thirdly, because of insufficient knowledge of potential risks. Once we add to that the fact that its growth is closely related to the preservation of biodiversity, agrobiodiversity, agriculture and the overall rural area, which is the basis for multifunctional agricultural development, the goal of the paper was determined. It was formulated based on advice from modern literature (Znaor, 1996), indicating that more intense growth of all fruit and agricultural crops has a unique goal, which is to increase yield. This can only be achieved through the application of modern chemical agents which are used to protect products that are being significantly increased. The use of synthetic chemical products not only changed the structure and quality of water, air and land, but the overall environment as well. It has increased the cost of production and the time during which pesticides and herbicides remain in the newly formed products. However, no one is claiming that the increase in production is not a civilizational achievement (Berenji, 2004), but we must acknowledge the fact that the greater loss is the annual number of reported cases of pesticide and herbicide poisoning - more than three million cases with lethal outcome for 
more than 220,000 people all over the world. Since garlic is only slightly dependent on the aforementioned substances, its intensive growth is a very wise choice.

It is of no use to try and obtain garlic in order to satisfy the needs based on the assumption of its multiple values, if we neglect its origin, quality and the fact that in some circumstances its consumption could be detrimental to human health (Cutler and Wilson, 2004).

Apart from pointing out the importance of garlic for people's health and cookery, the authors of this paper aimed at showing one way (technology) of garlic production on family farms in Serbia. Besides from performing an experiment under production conditions at two locations in Serbia, substantial data on achieved yield are also available. Based on the obtained data on yield, production technology and applied agro-technical measures, it is possible to perform calculations of costs of this production. By compiling calculations based on variable costs for the chosen garlic types, financial result which can be achieved in the chosen manner is shown.

\section{Materials and methods}

Over the last few years, due to the expansion of various illnesses (cancer, myocardial infarctions, diabetes mellitus and hypertension), the demand for garlic is constantly on the increase (Ried et al., 2010). One can find garlic of different origins and of wide price range in Serbia, related to both, the planting material and consumption-based garlic. Rough divisions can be made to registered garlic types of high quality, domestic unregistered types and garlic originally from China, which is mostly of poor quality and of the lowest price. Authors of this paper performed an experiment on two locations in Western Serbia with an aim to investigate yield of garlic which can be found in this part of the country on production conditions. The authors opted for one registered type of garlic of high quality (Bosut), two unregistered but present types called Zoza 51 and Visoka, as well as garlic of the unknown type originally from China.

The paper will precisely represent all the phases of growth and the preparations which had to be made prior to planting during vegetation and during the extraction of mature bulbs. All of the phases were planned with mathematical precision, from the soil preparation on the plots set aside for planting, to hanging the last garlic wreath on the nail to dry. At every step, attention was given as not to make even the slightest mistake. The first step was to select a plot on existing areas (fields) and to prepare the soil for planting. Plots which had not been used to grow any kind of agricultural crop were targeted. The plots had not been classified under Regulations for cadastral classification and land quality evaluation (Official Gazette of the Republic of Serbia), no. 61/2012, so we did not know which type of soil was found on the plots. No samples were taken from any of the plots prior to planting, even though the Agricultural Land Act (Official Gazette of the Republic of Serbia), no. 62/06, 65/08, 41/09, makes such provision). During the first week of September, agro-technical measures were taken: ploughing, the improvement in the structure and fertility of the land (the addition of humus, the improvement of biological and chemical activity) through a compulsory system of organic fertilization using solely manure. After the professional removal of smaller amounts 
of stones, roots, and other unnecessary elements, during the first week of October, the soil was ploughed again so that the larger clumps of dirt could be broken down into smaller pieces and mixed in with the distributed manure. These steps were taken on plot " $A$ " in Arilje, and then on plot " $B$ " in Barakovac (Novi Pazar), which are at a distance of exactly $140 \mathrm{~km}$ from each other.

On plot " $A$ " located in the municipality of Arilje (43 N 45' 02.75"; 20 E 06' 02.64"), with a size of $22.20 \mathrm{~m}$ in length and $18.00 \mathrm{~m}$ in width, that is, covering gross area of $400 \mathrm{~m}^{2}$, access paths were provided, "sidewalks" $40 \mathrm{~cm}$ in width on all four sides. In addition, for the purpose of easy access, work and communication, a pathway (used for communication) was left among the rows, $45 \mathrm{~cm}$ in width. After these measuring, $320 \mathrm{~m}^{2}$ were left available for planting with 48 (forty-eight) rows, each of which was $21.80 \mathrm{~m}$ long. For the planting of every type of garlic, 12 (twelve) rows were prepared, which were organized into planting fields. Plot " $A$ " contained six planting fields whose individual surface was $53 \mathrm{~m}^{2}(21.80 \mathrm{~m} \mathrm{x}$ $2,45 \mathrm{~m}$ ). The altitude of the planting plots was $342 \mathrm{~m}$, and the land rich in humus was loose and there was not any extensive presence of moisture in the soil. The need for irrigation was eliminated at the very beginning. The only danger which threatened the crops in plot " $A$ " was the use of chemical agents (pesticides and herbicides) which during spring are used by raspberry producers in the surrounding area to protect their raspberry shoots from insect and fungus infections.

Plot “B” Barakovac (Novi Pazar), (43 N 08' 29.17'”; 20 E 31'31.4”) with a length of 33.50 $\mathrm{m}$ and a width of $12.00 \mathrm{~m}$, is also bordered by access paths with a width of $40 \mathrm{~cm}$ on all four sides. The distance between the rows is $45 \mathrm{~cm}$ wide, and they were left for planting and fertilizing and the final extraction of the bulbs. After providing an area for the unimpaired movement during the performance of various activities (traffic), surface of this plot was also reduced to $320 \mathrm{~m}^{2}$ with 32 (thirty-two) rows $32.70 \mathrm{~m}$ long. Eight rows were prepared for each garlic type. The surface prepared for planting had 4 (four) planting fields covering an area of $80 \mathrm{~m}^{2}$ (32.70 m x $2.45 \mathrm{~m}$ ). The altitude of the plot was $497 \mathrm{~m}$. An interesting fact is that the plots planted in Arilje and in Novi Pazar are located at the same altitude as water processing plant. It is a coincidence in the true sense of the word. The soil is clay soil and partially the limestone found on fields. Prior to planting, the plot was only used as grazing land for sheep. It originally possessed certain fertilizer matter and right next to the property line, there is a well with abundance of water.

The finely ploughed soil is located East to West, along all 80 (eighty) rows, organized into 10 (ten) planting fields found on both plots. Wooden pegs were positioned and plastic thread was spread between them. Right next to them, using special tools (metal spoons), small planting rows were drawn at a depth of between 4 and $6 \mathrm{~cm}$. In each of the planting rows at a distance of between 10 and $11 \mathrm{~cm}$, small holes were dug for the seed material (the cloves) and a lot of time was spent determining the precise distance. Only after they had been "carved out" did the planting fields get their desired form. The preparatory work, the planting on the soil of plot " $A$ " 6 (six) and in plot " $B$ " 4 (four), the border access paths and the empty space between the rows, created an ambient which lead to exaltation. The overall preparation for planting was quite timely, and no problems were encountered. When both plots had been prepared 
professionally, and when planting could commence, three female workers were hired for the job, all of them with experience in growing garlic and other agricultural crops (raspberries, blackberries, fruit, vegetables, grain, aronia).

Identical technology of production was applied on both plots in question ("A" and "B"). While performing the experiment, special attention was given to determining production costs and to enforced agro-technical measures. Direct costing calculations for the chosen garlic types were compiled based on the experiment results and determined costs.

\section{Planting procedure}

Due to the desire for precision, preparations for planting were a very important operation. We made an effort to use many things from everyday life for different purposes. For example, apothecary scales were used for the precise measurement of the seed material (the cloves), measuring instruments which are used in technology, metal strips for measuring (length, width) and agricultural tools, the scales for measuring goods in bulk, timely transport of food for workers, etc. Measuring weight of up to 10 (ten) randomly selected bulbs of each type, in order to obtain their average weight, did not represent a problem. However, the separation and individual measuring of the cloves required a lot of precision. Material needed for the chemical protection of the seedlings and for fertilization during vegetation was prepared in a timely manner. Space meant for drying of garlic in wreaths, once it was extracted from the ground, was provided in airy locations under wooden beams into which, for this purpose, metal nails were inserted at equal intervals. The aim was to perform the exact same operations on both of the selected plots.

Proper selection of the type of seed material was of key importance for the final success of the production process. Based on the consulted literature (Nastovski at al., 2004), in the case of organic production of garlic, advantage is given to types/populations which are more adaptable to the local sub-climate conditions and which are resistant to harmful bio agents. Considering the fact it is recommended that the seed material originates from a certified organic production, there was no deviation from this rule, except for the use of seed material which originates from China. Thus, we made sure that the seed material originated from a competent supplier who raises his own high quality seed material and maintained it properly. For the purpose of this experiment $60 \mathrm{~kg}$ of seed material was procured, that is, cca $20 \mathrm{~kg}$ of each type of garlic, except for the Zoza 51 type, which was already in stock. Thus, the prepared seed material consisted of four types of garlic: first the aforementioned undetermined type which originated from China purchased from a reputable dealer with a registered company, which we will refer to in this paper as IQ 230 Tao. Its bulbs, on average weighed a little over 31 gr, had on average 8 (eight) "tired" cloves with an average weight of approximately 3.5 gr with ruptured skin (the protective cover). The second type of seed material is Bosut type, produced at the Institute for Agriculture and Vegetable Production in Novi Sad, purchased in original packs of $5 \mathrm{~kg}$ each. Its bulb was of high quality, of a pronounced white colour, round, with an average weight of approximately $40 \mathrm{gr}$. It had on average, 10 (ten) cloves weighing approximately 4 gr each. The third type was Zoza (51) and was a local product from vicinity of Barakovac (Novi Pazar), brought in from the village of Horizare (Macedonia), nearly 
13 years ago. Its bulbs on average, weighed in excess of $35 \mathrm{gr}$ and consisted of a standard average of 9 (nine) reddish cloves with a tight protective skin. The fourth type was Visoka produced on one of the plots in the village of the same name, in the municipality of Arilje, at a farm of a reliable and well-known farmer. The average weight of the bulb did not exceed $30 \mathrm{gr}$ and it had on average 9 (nine) small but firm cloves, each weighing a little over 3 gr.

The classified cloves were packaged into specially prepared cases so that they would not get mixed up before or during the planting. The seed material was completely dried, healthy and properly cleaned, so that each clove, which was very important, still had its skin (protective outer coating) which protected it in contact with the soil from damage and/or destruction. In plot " $A$ " the planting was performed manually on October $8^{\text {th }}, 2013$ in Arilje, and on plot " $B$ " Barakovac (Novi Pazar), also manually on October 9" 2013. Placing the seed material into the prepared holes on both plots began at exactly $8 \mathrm{AM}$ and took place in the following order:

- Rows I and V IQ 230 Tao,

- Rows II and VI Zoza (51),

- Rows III and VII Bosut, and

- Rows IV and VIII Visoka.

In each of the planting holes located in the rows, every clove was placed vertically, which was of special importance for the proper sprouting of young leaves and the formation of the future bulb. In the middle of the first field, on plot " $A$ ", that is, at $10.90 \mathrm{~m}$, in the first 4 (four) rows of the first planting field, the cloves were deliberately turned upside down so that their growth could be monitored during vegetation; whether they would sprout at all and whether they would develop. The same was done on plot " $B$ " but along a length of 16.35 $\mathrm{m}$, also in the first 4 (four) rows of the first planting field. These locations in the first fields in all 4 (four) planted rows for both plots, was specially marked. Each planting hole in the row in which the cloves were planted was covered with a layer of soil approximately 2 to 3 $\mathrm{cm}$ thick, which is relevant for two reasons. First, if the clove were positioned any deeper into the ground, it could take longer time for it to sprout. Secondly, if it were positioned any lower and covered with soil, the root would develop with more intensity and spread outside the row onto the surface, which would usually result in its drying. The planting on both plots was completed in the same amount of time, between 4 to 5 hours of effective work. Upon completion of the planting, the wooden pegs and the thread were removed. Only one wooden peg was left in the places where the cloves had been planted upside down on purpose, so that they could easily be seen. After the planting of the seed material on both planting fields, appropriate protective measures against weeds and pests were taken, as the literature recommended and special efforts were made for their destruction.

Tables 1 and 2 show data on the characteristics of seed material for both plots, prior to and during the planting. 
Table 1. Plot “ $A$ " - Arilje and the characteristics of planted seed material (in 2013)

\begin{tabular}{|l|c|c|c|c|c|}
\hline \multirow{2}{*}{\multicolumn{1}{|c|}{ Input }} & \multicolumn{4}{c|}{ Types of garlic } & \multirow{2}{*}{ Total } \\
\cline { 2 - 6 } & IQ 230 Tao & Bosut & Zoza 51 & Visoka & \\
\hline Planting rows & 12 & 12 & 12 & 12 & 48 \\
\hline Cloves planted in one row & 218 & 218 & 218 & 218 & \\
\hline Bulbs planted in one row & 24 & 22 & 24 & 23 & 93 \\
\hline Overall number of bulbs planted on the plot & 288 & 264 & 288 & 276 & 1,116 \\
\hline Average number of cloves per bulb & 9 & 10 & 9 & 9 & \\
\hline Average clove weight (gram) & 3.5 & 4.0 & 3.6 & 3.2 & \\
\hline Average bulb weight (gram) & 31.5 & 40.0 & 32.4 & 28.8 & \\
\hline Overall seed material per row (gram) & 756 & 880 & 778 & 662 & \\
\hline Overall seed material for 12 rows (kg) & 9.1 & 10.7 & 9.3 & 7.9 & 37 \\
\hline
\end{tabular}

Source: According to fieldwork information.

Table 2. Plot " $B$ " - Barakovac (Novi Pazar) and the characteristics of planted seed material (in 2013)

\begin{tabular}{|l|c|c|c|c|c|}
\hline \multirow{2}{*}{ Input } & \multicolumn{4}{c|}{ Types of garlic } & \multirow{2}{*}{ Total } \\
\cline { 2 - 5 } & IQ 230 Tao & Bosut & Zoza 51 & Visoka & \\
\hline Planting rows & 8 & 8 & 8 & 8 & 32 \\
\hline Cloves planted in one row & 327 & 327 & 327 & 327 & \\
\hline Bulbs planted in one row & 36 & 33 & 36 & 34 & 139 \\
\hline Overall number of bulbs planted on the plot & 288 & 264 & 288 & 276 & 1,116 \\
\hline Average number of cloves per bulb & 9 & 10 & 9 & 9 & \\
\hline Average clove weight (gram) & 3.5 & 4.0 & 3.6 & 3.2 & \\
\hline Average bulb weight (gram) & 31.5 & 40.0 & 32.4 & 28.8 & \\
\hline Overall seed material per row (gram) & 907 & 1,056 & 933 & 788 & \\
\hline Overall seed material for 8 rows (kg) & 9.1 & 10.7 & 9.3 & 7.9 & 37 \\
\hline
\end{tabular}

Source: According to fieldwork information.

\section{Results and discussion}

Extraction of garlic starts when the tree and its leaves start changing colour from brown to yellow. But, the literature also warns that the occurrence of the yellow or brown colour does not only signal the onset of the extraction period, but also the occurrence of certain illnesses (McGee, 2004). In this case, the lack of green colour on leaves is a sign that the extraction process should begin, indicating that the plants were fully formed. We acted in accordance with the advice offered in the relevant literature, which promotes agro-technical measures and procedures (Trienekens, 2011). It said that the extraction should be done sooner rather than later, which has proven to be advantageous.

In addition to noting a change in colour during the first week of May, according to our assessment, over $60 \%$ of the garlic leaves on both plots were lying on the ground, which was also an indication that extraction should take place as soon as possible. 
Just to be sure using a random sample technique, several bulbs were extracted from various rows of each type of garlic for experimental observation. It was determined that the external shape of the bulbs was well protected by bulging, tight skin and that the dimensions were well-formed and cloves were large and fully developed. The extraction and cleaning, based on the recommendations from the literature, were carried out in the morning hours first on plot " $A$ " in Arilje on June $8^{\text {th }}$, and one day later on June $9^{\text {th }}, 2014$ on plot " $B$ " Barakovac (Novi Pazar), which means that the garlic had spent full nine months in the ground.

Due to nice weather on both plots, we were able to apply the methods used in California, which are unique in the world, where the recently extracted bulbs are dried in the field itself (Agamalian and Kurtz, 1989), positioned along the rows for several days. Once they were extracted, they were typed out, collected and covered with a see-through tarp, and the excess leaves were removed so that they would not directly be exposed to the sun during the three-day drying period. The shape, colour and firmness of the bulbs indicated that they were healthy.

In both planting fields, in one case, protective measures from the mites and rot had to be performed (Martel and Cassidy, 2004). These were performed to a smaller extent primarily due to insufficient knowledge regarding the use of chemicals (pesticides). During the second week of March, the plants were fertilized using artificial means made of ammonium nitrate - AN with $12 \mathrm{~kg}$ per plot. None of the phases of the preparatory process were especially difficult, except for the constant kneeling when the cloves were being planted in the holes and then covered with dirt. That is the greatest problem in the case of growing garlic, and it seems to be a very important reason for larger planting fields to be avoided. New garlic was removed from the field by hand, and then the damaged or infected parts were removed. On some of the bulbs there were clumps of soil, especially from plot " $A$ " in Arilje which had more clay soil. This led us to the question of whether or not the bulbs should be washed. The relevant literature also shows signs of a longterm controversy on whether freshly-extracted bulbs from the ground should be washed. Some claim that washing them is undesirable (Etoh, 1985), since it can lead to additional moisture which could cause the bulbs to decay. Others (Simon and Jenderek, 2003) think that washing the soil off the bulbs which were grown on softer" soil with enough humus is unnecessary, because they are easy to clean.

However, if garlic was grown on "heavier" soil, then its cleaning is more difficult and washing the bulbs with a stream of water from a garden hose is recommended. One should hold 5 to 6 bulbs in his hand and rotate them so that the water could wash off each side of the bulb. Once the dirt has been washed off the bulbs, they are usually stored on a dry surface (shelves or a tarp), so as to give them time to dry. If they are meant to be used as seed material, washing the soil off them is unnecessary since it dries off during time. It can be shaken off and it falls off by itself, leaving the bulb clean. In this case washing the bulbs was not necessary. The clumps of soil were easily removed, since during the three-day drying period they were able to fall off. In Tables 3 and 4 are shown the data on the results of growing garlic on both plots. 
Table 3. Plot " $A$ " - Arilje - total yield of garlic (in 2014)

\begin{tabular}{|l|r|r|r|r|r|}
\hline \multirow{2}{*}{ Outp u t } & \multicolumn{3}{|c|}{ Types of garlic } & \multirow{2}{*}{ Total } \\
\cline { 2 - 5 } & IQ 230 Tao & Bosut & Zoza 51 & Visoka & 12 \\
\hline Rows for extraction & 12 & 12 & 12 & 12 \\
\hline The number of bulbs extracted from one row & 189 & 193 & 191 & 193 & \\
\hline The average number of extracted bulbs per planting field & 2,270 & 2,316 & 2,292 & 2,316 & 9,194 \\
\hline The average number of cloves per bulb & 8 & 9 & 8 & 8 & \\
\hline The average weight of the cloves (gram) & 3.6 & 4.2 & 3.8 & 3.5 & \\
\hline The average weight of one bulb (gram) & 28.8 & 37.8 & 30.4 & 28.0 & \\
\hline The overall yield of new garlic per planting field (gr) & 65,318 & 87,545 & 69,677 & 64,848 & 287,388 \\
\hline Overall yield - the extracted amount of garlic (kg) & 65.3 & 87.6 & 69.7 & 64.8 & 287.4 \\
\hline
\end{tabular}

Source: Data analysis according to fieldwork information/results.

Table 4. Plot " $B$ " - Barakovac (Novi Pazar) - total yield of garlic (in 2014)

\begin{tabular}{|l|r|r|r|r|r|}
\hline \multirow{2}{*}{ Output } & \multicolumn{3}{c|}{ Types of garlic } & \multirow{2}{*}{ Total } \\
\cline { 2 - 5 } & IQ 230 Tao & Bosut & Zoza 51 & Visoka & \\
\hline Rows for extraction & 8 & 8 & 8 & 8 & 32 \\
\hline The number of bulbs extracted from one row & 282 & 295 & 291 & 294 & \\
\hline The average number of extracted bulbs per planting field & 2,256 & 2,360 & 2,328 & 2,352 & 9,296 \\
\hline The average number of cloves per bulb & 8 & 9 & 8 & 8 & \\
\hline The average weight of the cloves (gram) & 3.7 & 4.2 & 4.0 & 3.6 & \\
\hline The average weight of one bulb (gram) & 29.6 & 37.8 & 32.0 & 28.8 & \\
\hline The overall yield of new garlic per planting field (gr) & 66,778 & 89,208 & 74,500 & 67,738 & 298,224 \\
\hline Overall yield - the extracted amount of garlic (kg) & 66.8 & 89.2 & 74.5 & 67.7 & 298.2 \\
\hline
\end{tabular}

Source: Data analysis according to fieldwork information/results.

The measuring was first carried out on plot " $A$ " in Arilje, based on the types of garlic, and it was determined that the smallest yield was noted for the Chinese type of $I Q 230 \mathrm{Tao}$, which was not surprising based on the quality of the seed material. The highest yield on both plots was obtained for Bosut type, followed by type Zoza 51. Visoka type is the standard and showed better results than the Chinese type. On plot " $A$ " in Arilje an overall yield of 287.4 $\mathrm{kg}$ was obtained, which is 7.8 times greater than the used $37 \mathrm{~kg}$ of seed material. On plot " $B$ " in Barakovac (Novi Pazar) for the used $37 \mathrm{~kg}$ of seed material, a yield which was more than 8.1 times greater was obtained, $298.2 \mathrm{~kg}$. The data in tables 5 and 6 show the relationship between the used seed material and the realized yield, determined through the measuring prior to forming the wreaths of garlic, that is, prior to drying.

Following the measuring, three female workers began making the wreaths and removing the excess leaves. One of the workers placed the wreaths on metal nails nailed into the wooden beams of both spaces, at a prescribed distance, so that the drying began in the draft under the same conditions. By putting garlic to dry, practical part of the experiment was over since all data for determining of costs and compiling of appropriate calculations were familiar. It was foreseen to sell the produced garlic locally, which meant no extra costs of transport or marketing. 
Table 5. Plot " $A$ " - Arilje - total yield and ratio between the planted and extracted quantities of garlic

\begin{tabular}{|l|c|c|c|c|c|}
\hline \multirow{2}{*}{ Results } & \multicolumn{4}{c|}{ Types of garlic } & \multirow{2}{*}{ Total } \\
\cline { 2 - 5 } & IQ 230 Tao & Bosut & Zoza 51 & Visoka & 48 \\
\hline Rows (planted-extracted) & 12 & 12 & 12 & 12 & 1,116 \\
\hline Overall planted bulbs & 288 & 264 & 288 & 276 & 9,194 \\
\hline Overall extracted bulbs & 2,270 & 2,316 & 2,292 & 2,316 & $8.2: 1$ \\
\hline Extracted: planted bulbs & $7.9: 1$ & $8.8: 1$ & $8.0: 1$ & $8.4: 1$ & 36.9 \\
\hline Overall seed material (kg) & 9.1 & 10.6 & 9.3 & 7.9 & 287.4 \\
\hline Overall yield (kg) & 65.3 & 87.6 & 69.7 & 64.8 & $7.8: 1$ \\
\hline Overall yield: overall seed material & $7.2: 1$ & $8.3: 1$ & $7.5: 1$ & $8.2: 1$ & \\
\hline
\end{tabular}

Source: Data analysis according to fieldwork information/results.

Table 6. Plot “ $B$ ” - Barakovac (Novi Pazar) - total yield and ratio between the planted and extracted quantities of garlic

\begin{tabular}{|l|c|c|c|c|c|}
\hline \multirow{2}{*}{ Results } & \multicolumn{4}{c|}{ Types of garlic } & \multirow{2}{*}{ Total } \\
\cline { 2 - 5 } & IQ 230 Tao & Bosut & Zoza 51 & Visoka & \\
\hline Rows (planted-extracted) & 8 & 8 & 8 & 8 & 32 \\
\hline Overall planted bulbs & 288 & 264 & 288 & 276 & 1,116 \\
\hline Overall extracted bulbs & 2,256 & 2,360 & 2,328 & 2,352 & 9,296 \\
\hline Extracted : planted bulbs & $7.8: 1$ & $8.9: 1$ & $8.1: 1$ & $8.5: 1$ & $8.3: 1$ \\
\hline Overall seed material $(\mathrm{kg})$ & 9.1 & 10.6 & 9.3 & 7.8 & 36.9 \\
\hline Overall yield (kg) & 66.8 & 89.2 & 74.5 & 67.7 & 298.2 \\
\hline Overall yield : overall seed material & $7.3: 1$ & $8.4: 1$ & $8.0: 1$ & $8.7: 1$ & $8.1: 1$ \\
\hline
\end{tabular}

Source: Data analysis according to fieldwork information/results.

In order to calculate economic result of growing garlic, analytic method based on direct costing calculation was used (Andrić, 1998, Gogić, 2009). This methodology is especially favourable for small households whose fixed and general costs are small or when their allocation to different products is complicated.

When calculating the value of production, one had to take into consideration an extremely complicated garlic market in Serbia which is a subject to strong seasonal and geographical fluctuations. Based on data from practice and depending on the aforementioned factors, we have come to a conclusion that the garlic from China costs from $100 \mathrm{RSD} / \mathrm{kg}$ to $150 \mathrm{RSD} /$ $\mathrm{kg}$, domestic garlic of an unknown type and of different quality costs from $150 \mathrm{RSD} / \mathrm{kg}$ to $250 \mathrm{RSD} / \mathrm{kg}$, while a well-known and high quality garlic of "Bosut" type, costs from 250 $\mathrm{RSD} / \mathrm{kg}$ to over $400 \mathrm{RSD} / \mathrm{kg}$. During calculation of the value of production, out starting point was the average price of garlic of different origin of the seed material in Serbia and we have neglected the current prices of garlic at the locations of the experiment.

Another significant datum when calculating the value of production is weight loss of garlic during drying. Practice has shown that garlic loses $25-30 \%$ of its mass from the moment of being dried to the moment when it is ready to be sold. Assuming that not all quantity of garlic will be sold at that moment, more weight loss should be calculated in by the end of sale which amounts to $5-15 \%$. Thus, garlic loses between $30 \%$ and $40 \%$ of its mass from the extraction 
to sale providing that the sale does not last for too long.

Apart from direct costing calculations during production, there are also costs of the seed material, labour costs, fuel costs and costs of externally engaged machinery.

Considering that identical technology was applied in growing different types of garlic, the difference in obtained contribution margin comes from the price of the seed material and its quantity, as well as from the price and the quantity of obtained garlic.

Table 7. Direct costing calculation for two types of garlic

\begin{tabular}{|c|c|c|c|c|c|c|c|c|}
\hline \multirow[b]{2}{*}{ Description } & \multicolumn{2}{|c|}{ Quantity } & \multirow[b]{2}{*}{$\mathbf{U M}$} & \multirow{2}{*}{$\begin{array}{c}\text { Price } \\
\text { per } \\
\text { UM }\end{array}$} & \multicolumn{4}{|c|}{ Overall $€$} \\
\hline & $\begin{array}{l}\text { Plot } \\
\text { "A" }\end{array}$ & $\begin{array}{l}\text { Plot } \\
\text { "B" }\end{array}$ & & & $\begin{array}{l}\text { Plot } \\
\text { "A" }\end{array}$ & $\begin{array}{l}\text { Plot } \\
\text { "B" }\end{array}$ & $\begin{array}{l}\text { Plot } \\
\text { "A" }\end{array}$ & $\begin{array}{l}\text { Plot } \\
\text { "B" }\end{array}$ \\
\hline I. YIELD (after drying loses of $35 \%$ ) & & & $\mathrm{Kg}$ & EUR & EUR & EUR & $€ / 100 \mathrm{~m}^{2}$ & $€ / 100 \mathrm{~m}^{2}$ \\
\hline Bosut - planting area $80 \mathrm{~m}^{2}$ & 56.9 & 58.0 & $\mathrm{Kg}$ & 2.5 & 142.4 & 145.0 & 177.9 & 181.2 \\
\hline Visoka - planting area $80 \mathrm{~m}^{2}$ & 42.1 & 44.0 & $\mathrm{Kg}$ & 1.7 & 71.6 & 74.8 & 89.5 & 93.5 \\
\hline II. Variable costs - Bosut & & & & & 95.8 & 95.8 & 119.7 & 119.7 \\
\hline II. Variable costs - Visoka & & & & & 74.1 & 74.1 & 92.7 & 92.7 \\
\hline Seed material - Bosut & 10.7 & 10.7 & $\mathrm{Kg}$ & 3.5 & 37.5 & 37.5 & 46.8 & 46.8 \\
\hline Seed material - Visoka & 7.9 & 7.9 & $\mathrm{Kg}$ & 2.0 & 15.8 & 15.8 & 19.8 & 19.8 \\
\hline Fertilizer $-\mathrm{AN}$ & 3.0 & 3.0 & $\mathrm{Kg}$ & 0.4 & 1.3 & 1.3 & 1.6 & 1.6 \\
\hline Fertilizer-manure & 187.5 & 187.5 & $\mathrm{Kg}$ & 0.0 & 3.8 & 3.8 & 4.7 & 4.7 \\
\hline Soil preparation - ploughing and tiling & 0.5 & 0.5 & $\mathrm{H}$ & 30.0 & 15.0 & 15.0 & 18.8 & 18.8 \\
\hline Planting the seed material & 3.8 & 3.8 & $\mathrm{H}$ & 4.0 & 15.0 & 15.0 & 18.8 & 18.8 \\
\hline Weed removal and plant protection & 1.3 & 1.3 & $\mathrm{H}$ & 4.0 & 5.0 & 5.0 & 6.3 & 6.3 \\
\hline Extraction and storage & 2.3 & 2.3 & $\mathrm{H}$ & 4.0 & 9.0 & 9.0 & 11.3 & 11.3 \\
\hline Plastic thread & 66.0 & 66.0 & M & 0.0 & 2.0 & 2.0 & 2.5 & 2.5 \\
\hline Plant protection - ridomil (R) MZ72/WP & 0.5 & 0.5 & Litter & 1.2 & 0.6 & 0.6 & 0.8 & 0.8 \\
\hline Worker transport - fuel & 5.0 & 5.0 & Litter & 1.4 & 6.8 & 6.8 & 8.4 & 8.4 \\
\hline III. Contribution margin (I-II) - Bosut & & & & & 46.6 & 49.2 & 58.2 & 61.5 \\
\hline III. Contribution margin (I-II) - Visoka & & & & & -2.5 & 0.7 & -3.2 & 0.8 \\
\hline
\end{tabular}

Source: Author's calculation; Note: 1 EUR $=118$ RSD.

Table 7 shows that according to the aforementioned technology of production and work organization, "Visoka" type gives poor economic results while contribution margin on plot " $\mathrm{B}$ " is barely positive, while plot "A" has negative value.

Production of "Bosut" type shows extremely positive contribution margin which resumed by square meter $\left(100 \mathrm{~m}^{2}\right)$, is around 60 EUR. Instead of hectare for the unit of area for which the contribution margin was calculated, we have taken 1 are $\left(100 \mathrm{~m}^{2}\right)$ as the unit of area since this is the most frequently used unit with small individual farm producers.

Contribution margin value is more significantly influenced by the value of production than by the direct costing calculations which differ only in the value of cost for procuring the seed material. Significant difference in the value of production is being influenced by both the yield of "Bosut" type as well as the significantly higher price which can be achieved for garlic of this type, with regard to domestic and Chinese types. 
Based on the obtained values for contribution margin of production of "Bosut" $i$ "Visoka" garlic types, certain conclusions can be drown for the other two types from the experiment. Considering that the domestic unregistered type "Zoza 51" has shown similar yield values as well as "Visoka", all the aforementioned conclusions could be applied to this type, too. Chinese type of garlic cannot be recommended for growing, mostly because of low value in yield, where the contribution margin would be even more negative even if the same technology was applied.

\section{Conclusion}

The subject of this research was production and economic results of growing four different types of garlic on family households in Western Serbia. For this experiment, two plots in municipalities of Arilje and Novi Pazar had been chosen. Based on the result of production of determined costs of production, the direct costing calculation has been compiled for the chosen types.

The experiment under production conditions at the aforementioned locations included four types of "the fall" garlic abundant in Western Serbia, of whom one type is the registered type of "Bosut", two are domestic unregistered types but are abundant in the aforementioned municipalities. The forth type is an unknown type from China, chosen above all because of the growing abundance of it in Serbia.

The experiment started in October 2013 and finished in July 2014 (lasts for 9 months). After extracting the garlic was measured and stored.

Based on the achieved results, it can be concluded:

- Type "Bosut" achieved the highest yield on both plots (87.6 kg on plot "A" and $89.2 \mathrm{~kg}$ on plot "B"),

- Domestic unregistered type called "Zoza 51" was placed as second with $144.2 \mathrm{~kg}$ in total $(69.7 \mathrm{~kg}$ on plot "A" and $74.5 \mathrm{~kg}$ on plot "B"),

- Chinese type called "IQ 230 Tao" has had the lowest yield in total $132.1 \mathrm{~kg}$ on both parcels, while the domestic unregistered type "Visoka" gained almost the same result with total yield of $132.5 \mathrm{~kg}$.

Based on the production results from the experiment and determined costs, it was made the direct costing calculation for "Bosut" and "Visoka" types, which shows:

- For applied technology and production organization at two examined locations where was grown "Bosut" type of garlic, contribution margin is positive and amounts around $60 \mathrm{EUR} / 100 \mathrm{~m}^{2}$,

- Contribution margin for garlic type "Visoka" under the same conditions, is negative on location "A" and barely positive on location "B".

According to the obtained results from both the experiment of production and the calculation as well, one can conclude that is justifiable to grow "Bosut" type, under the aforementioned conditions, for both production and economic reasons. Production of other garlic types cannot be recommended under the same conditions. 


\section{References}

1. Agamalian, H. S., Kurtz, E. A. (1989): Garlic weed competition, California Agriculture, January-February, pp. 11-12, available at: https://ucanr.edu/ repositoryfiles/ca4301p11-62152.pdf

2. Alnaqeeb, M. A, Thomson, M., Bordia, T., Ali, M. (1996): Histopathological effects of garlic on liver and lung of rats, Toxicol. Lett., vol. 85, no. 3, pp. 157-64.

3. Andrić, J. (1998): Troškovi i kalkulacije u poljoprivrednoj proizvodnji, treće dopunjeno izdanje, Savremena administracija, Beograd, p. 181.

4. Anwar, A., Groom, M., Sadler-Bridge, D. (2009): Garlic: from nature's ancient food to nematicide, Pesticide News, no. 84(June), pp. 18-20.

5. Berenji, J. (2004): Organsko oplemenjivanje bilja, Zbornik abstrakta III Kongresa genetičara Srbije, Subotica, p. 85.

6. Block, E. (2010): Garlic and Other Alliums: the Lore and the Science, Royal Society of Chemistry, Cambridge, UK.

7. Cutler, R. R., Wilson, P. (2004): Antibacterial activity of a new, stable, aqueous extract of allicin against methicillin-resistant Staphylococcus aureus, Br. J. Biomed. Sci., vol. 52, no. 3, pp. 71-74.

8. Engeland, R. L. (1991): Growing Great Garlic: the Definitive Guide for Organic Gardeners and Small Farmers, Filaree Productions, Okanogan, WA.

9. Etoh, T. (1985): Studies on the sterility in garlic. Allium sativum L., Memoirs of the faculty of agriculture of Kagoshima University, vol. 21, pp. 77-132.

10. Gogić, P. (2009): Teorija troškova sa kalkulacijama u proizvodnji i preradi poljoprivrednih proizvoda, Beograd, Mladost biro.

11. Jones, W., Goebel, R. J. (2001): Garlic and Health, In Watson R. R.: Vegetables, Fruits, and Herbs in Health Promotion, Boca Raton: CRC Press, pp. 205-216.

12. Martel, B., Cassidy, K. (2004): Chemical Risk Analysis: A Practical Handbook, Butterworth - Heinemann, London, UK.

13. McGee, H. (2004): The Onion Family: Onions, Garlic, Leeks, In: On Food and Cooking (Revised Edition), Scribner, New York, USA, pp. 310-313.

14. Nastovski, T., Chatzopoulou, P., Radovanović, D., Koutsos, T. (2004): Comparative investigation of organic Chamomile [C. Recuita (L) Rauch] production in different agroecological regions of Greece and Serbia, proceedings of IV CMAPEEC, Isai, Rumunia, pp. 183-187.

15. Pravilniku za katastarsko klasiranje i bonitiranje zemljišta, Službeni glasnik Republike Srbije, br. 61/2012.

16. Pritts, M. (2009): High Tunnel Raspberries and Blackberries, New York Fruit Quarterly, vol. 17, no. 3, pp. 13-16.

17. Renoux, V. (2005): For the Love of - Garlic: The Complete Guide to Garlic Cuisine, Square One Publishers Inc., NY, USA.

EP 2014 (61) 4 (915-928) 
18. Ried, K., Frank, O. R., Stocks, N. P. (2010): Aged garlic extract lowers blood pressure in patients with treated but uncontrolled hypertension: a randomised controlled trial, Maturitas vol. 67, no. 2, pp. 144-150.

19. Schwartz, H. F., Krishna, S. M. (1999): Compendium of Onion and Garlic Diseases, the American Phytopathological Society, St. Paul, USA.

20. Simon, P. W., Jenderek, M. M. (2003): Flowering, Seed Production, and the Genesis of Garlic Breeding, Plant Breeding Reviews, vol. 23, pp. 211-244.

21. Trienekens, J. H. (2011): Agricultural Value Chains in Developing Countries: A Framework for Analysis, International Food and Agribusiness Management Review, vol. 14, no. 2, pp. 51-82.

22. Verma, V., Singh, R., Tiwari, R. K., Srivastava N., Verma, A. (2012): Antibacterial activity of extracts of Citrus, Allium \& Punica against food borne spoilage, Asian Journal of Plant Science and Research, vol. 2, no. 4, pp. 503-509.

23. Zakon o poljoprivrednom zemljištu, Službeni glasnik Republike Srbije, br. 62/06, 65/08, 41/09.

24.Znaor, D. (1996): Ekološka poljoprivreda, Nakladni zavod GLOBUS, Zagreb.

\title{
PROIZVODNE I EKONOMSKE SPECIFIČNOSTI UZGOJA RAZLIČITIH SORTI BELOG LUKA
}

\author{
Ibrahim Totic ${ }^{3}$, Stevan Čanak
}

\begin{abstract}
Sažetak
Beli luk poseduje ogroman značaj kako za ljudsko zdravlje, tako i za kulinarstvo. Ovoje biljna kultura čija proizvodnja nikako ne ugrožava agro i eko-sistem, odnosno koja je od posebnog značaja u procesu proizvodnje organske hrane. S obzirom da se uzgoj belog luka zasniva na primeni agro-ekoloških i agro-ekonomskih principa, radom se daje opis toka procesa pripreme zemljišta za sadnju, tehnologija sadnje i primena neophodnih agro-tehnoloških mera. Takođe, dat je i prikaz osnovnih karakteristika sadnog materijala, kao i tehnologija vađenja i skladištenja belog luka. Predmet istraživanja je utvrđivanje prinosa kod različitih sorti belog luka gajenih na dve različite lokacije u Srbiji. Poret toga, rad ima za cilj da utvrdi troškove proizvodnje, i prikaže rezultate kalkulacija zasnovanih na varijabilnim troškovima, te da uporedi dobijene ekonomske rezultate u proizvodnji različitih sorti belog luka na malim porodičnim gazdinstvima.
\end{abstract}

Ključne reči: beli luk, tehnologija proizvodnje, marža pokrića.

3 Doc. dr Ibrahim Totić, Departman za ekonomske nauke, Državni univerzitet u Novom Pazaru, Vuka Karadžića nn, 36300 Novi Pazar, Srbija, Telefon: +381 203177 52, E-mail: itotic@np.ac.rs

4 Dr Stevan Čanak, asistent, Departman za hemijsko-tehnološke nauke, Državni univerzitet u Novom Pazaru, Vuka Karadžića nn, 36300 Novi Pazar, Srbija, Telefon: +381 203177 52, E-mail: $\underline{\text { scanak@np.ac.rs }}$ 